\title{
PENERAPAN KONSEP SMART RUBBISH MENJADI PHOTO CORNER SEBAGAI IDENTITAS WISATA MLOKO SEWU
}

\author{
Nurhuda $^{1}$, Elana Era Yusdita ${ }^{2}$, Herlin Rosalina Febriyanti ${ }^{3}$, Handoko Endro Seputro ${ }^{4}$ \\ Universitas PGRI Madiun \\ Email: noerhuda35@gmail.com
}

\begin{abstract}
The purpose of this article is to describe the results of implementing ideas through community service activities in answering the problem of inorganic waste at Mloko Sewu tourist sites, accompanied by steps and procedures for implementation. This article writing method uses qualitative research methods with a descriptive approach. The solution was given in the form of a smart rubbish concept with the final result in the form of a photo corner that has been realized in the Mloko Sewu tour. The application of the smart rubbish concept is expected to provide tourists with education on how inorganic waste should be handled in smart and creative ways, so that this concept can become a tourism identity especially in Mloko Sewu tourism.
\end{abstract}

Keywords: Rubbish Recycling, Photo Spot, Outreach Program, Tourism Village

\begin{abstract}
Abstrak. Penulisan artikel ini bertujuan untuk mendeskripsikan hasil implementasi gagasan melalui kegiatan pengabdian kepada masyarakat dalam menjawab permasalahan sampah anorganik di lokasi wisata Mloko Sewu, disertai dengan langkah serta prosedur pelaksanaannya. Metode penulisan artikel ini menggunakan metode penelitian kualitatif dengan pendekatan deskriptif. Solusi yang diberikan berupa konsep smart rubbish dengan hasil akhir berupa photo corner yang telah terealisasi di wisata Mloko Sewu. Penerapan konsep smart rubbish ini diharapkan mampu memberikan nilai edukasi kepada para wisatawan tentang bagaimana sampah anorganik selayaknya harus ditangani dengan cara-cara cerdas dan kreatif, sehingga konsep ini dapat menjadi identitas wisata khususnya di wisata Mloko Sewu.
\end{abstract}

Kata kunci: Daur Ulang Sampah, Spot Foto, Pengabdian Masyarakat, Desa Wisata

\section{PENDAHULUAN}

Sektor pariwisata merupakan salah satu sektor yang sangat potensial untuk dikembangkan menjadi salah satu sumber pendapatan daerah. Pariwisata dipandang menjadi salah satu kegiatan yang memiliki multidimensi dari rangkaian sebuah proses pembangunan, dimana pembangunan sektor ini memiliki keterkaitan terhadap aspek budaya, sosial, ekonomi dan politik (Hijriati \& Mardiana, 2015). Tujuan utama kepariwisataan adalah untuk meningkatkan pendapatan nasional dalam rangka untuk meningkatkan tingkat kesejahteraan masyarakat, meningkatkan kemakmuran rakyat, untuk mendorong pembangunan daerah, memperluas dan menciptakan kesempatan kerja serta memupuk rasa cinta tanah air dan mempererat hubungan persahabatan antar bangsa (RI, 2009). Di samping itu, adanya sektor pariwisata juga mempercepat pertumbuhan ekonomi masyarakat sekitar. Sektor pariwisata juga berperan dalam meningkatkan tingkat permintaan baik dalam segi konsumsi maupun investasi melalui peran para wisatawan. Selain dampak positif tersebut, dengan banyaknya wisatawan yang berkunjung juga terdapat dampak negatif. Salah satu dampak negatif yang ditimbulkan atas munculnya tempat wisata yaitu banyaknya sampah yang ditinggalkan oleh para wisatawan (Hijriati \& Mardiana, 2015). Salah satu jenis sampah yang paling banyak dijumpai di lokasi wisata adalah sampah anorganik berupa botol bekas. Sebenarnya adanya sampah botol ini juga dapat menjadi peluang tersendiri jika mampu memanfaatkannya dengan baik. Pengelolaan sampah mendapat perhatian khusus dari pemerintah karena merupakan salah satu dari sekian banyak permasalahan negara (RI, 2008). Pengelolaan ini diharapkan dapat memberikan manfaat secara bagi masyarakat secara ekonomi, ramah pada lingkungan, dan mengubah perilaku masyarakat itu sendiri (RI, 2008).

Sampah yang tidak mudah membusuk diklasifikasikan sebagai sampah anorganik, seperti pembungkus makanan, kantong plastik, gelas dan botol minuman, kaleng dan sebagainya (PS, 2008). Sampah jenis ini dikategorikan sebagai sampah anorganik dikarenakan sulit terdegradasi secara alami oleh alam. Konsep smart rubbish menjadi salah satu alternatif yang dapat digunakan untuk menangani permasalahan akan sampah di lokasi wisata, khususnya sampah botol. Konsep ini mengusung salah satu prinsip yang diterapkan dalam pemanfaatan sampah anorganik (4R) yaitu recycle (mendaur ulang). Sampah botol akan didaur ulang menjadi sebuah 
spot foto (photo corner) yang akan menunjang destinasi wisata tersebut melalui sebuah konsep pendaulangan sampah yang memiliki nilai estetika tersendiri. Smart rubbish ini dapat menjadi salah satu daya tarik wisatawan dengan output dapat menjadi identitas wisata yang dapat menarik minat para wisatawan.

Konsep smart rubbish ini merupakan hasil rancangan pengabdian masyarakat Badan Eksekutif Mahasiswa (BEM) Universitas PGRI Madiun melalui Program Hibah Bina Desa (PHBD) dari Kementerian Riset, Teknologi dan Pendidikan Tinggi (Menristekdikti) yang lolos didanai tahun 2018. Konsep smart rubbish direalisasikan pada wisata Mloko Sewu. Wisata ini merupakan salah satu destinasi wisata baru yang terletak di dusun Prumbon, desa Pupus, Kecamatan Ngebel kabupaten Ponorogo, Jawa Timur. Wisata ini menyuguhkan pemandangan Telaga Ngebel yang telah terlebih dahulu populer sebagai destinasi wisata, dari puncak bukit dengan variasi pemandangan telaga dan degradasi warna pepohonan serta kombinasi warna biru dari keindahan langit Ponorogo. Konsep Smart Rubbish menjadi salah satu solusi dari permasalahan akan sampah di lokasi wisata sekaligus memberikan nilai edukasi bagaimana sampah selayaknya harus ditangani.

Artikel ini bertujuan untuk mendeskripsikan hasil realisasi dari ide/gagasan penanganan sampah botol di lokasi wisata dengan konsep smart rubbish, dimana objek utama dari konsep ini berupa sampah botol yang banyak dijumpai di lokasi wisata Mloko Sewu.

\section{METODE PELAKSANAAN}

Metode yang digunakan dalam penulisan artikel ini adalah metode penelitian kualitatif dengan pendekatan deskriptif. Studi deskriptif sengaja dipilih karena studi ini sangat cocok digunakan dalam menguraikan hasil pengabdian kepada masyarakat yang berisi kegiatan, dikarenakan dapat menjelaskan sebuah situasi tertentu (Sekaran \& Bougie, 2017). Observasi

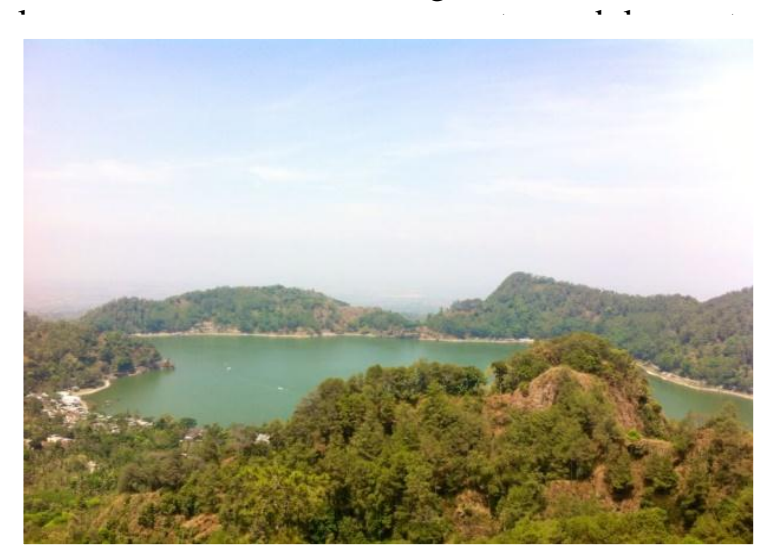

merupkan metode yang digunakan dalam pelaksanaan pengabdian ini. Observasi dilaksanakan pada awal kegiatan untuk mengetahui sejauh mana kondisi masyarakat sasaran, wawancara dilaksanakan untuk menggali informasi serta untuk mencari referensi sebanyak-banyaknya dengan berbagai sudut pandang atas lokasi yang akan dijadikan sasaran pengabdian, dan dokumentasi dilaksanakan untuk menunjang kepentingan laporan atas setiap tahan pelaksanaan dari pengabdian tersebut.

Studi pustaka dilakukan melalui berbagai sumber dan referensi mulai dari buku, artikel, jurnal dan akses jejaring internet yang sesuai dengan kebutuhan informasi atas program yang dilaksanakan sekaligus untuk menunjang kepentingan penyusunan artikel ini. Metode pelaksanaan pengabdian ini juga terbagi atas beberapa tahap pelaksanaan diantaranya, tahap sosialisai, tahap pendampingan, tahap monitoring dan evaluasi. Tahap sosialisasi digunakan untuk mensosialisasikan program kepada masyarakat sasaran yang akan merealisasikan program, tahap pendampingan dilaksanakan untuk mengawasi serta mengarahkan dalam merealisasikan program, tahap monitoring dan evaluasi dilaksanakan untuk mengawal berjalannya program sekaligus untuk mengevaluasi bagaimana setelah program telah terealisasi.

\section{HASIL DAN PEMBAHASAN \\ Hasil Data dan Analisi}

Ngebel merupakan salah satu kecamatan yang berada di Kabupaten Ponorogo, Jawa Timur, dengan jumlah penduduk \pm 23.356 jiwa, yang tersebar di delapan desa, diantaranya desa Talun, Ngrogung, Ngebel, Gondowido, Sahang, Sempu, Wangir Lor, dan Pupus. Letak geografisnya yang berada di daerah pegunungan, menjadikan kecamatan Ngebel menyimpan berjuta potensi anugerah dari sang pencipta. Telaga Ngebel merupakan salah satu potensi alam yang dimiliki oleh bumi Reog ini. Telaga Ngebel menyuguhkan keindahan telaga yang menimbulkan takjub bagi setiap pasang mata yang melihatnya. Keindahan

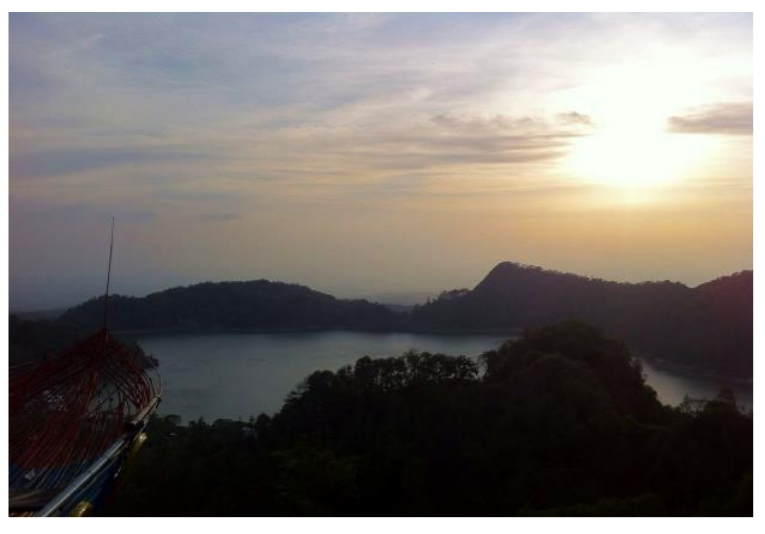

Gambar 2. Sunset di Mloko Sewu 
Banyak wilayah kecamatan Ngebel yang memiliki potensi lain yang tidak kalah dengan keindahan telaga Ngebel. Salah satu desa yang kaya akan potensi tersebut yaitu desa Pupus. Desa ini terletak di atas desa Ngebel yang juga menyimpan potensi luar biasa. Dapat dikatakan desa Pupus adalah desa yang berposisi paling atas dibandingkan desa lainnya di kecamatan Ngebel, sehingga tidak dapat dipungkiri jika dari desa ini seluruh pemandangan desa Ngebel dapat dilihat dari kejauhan. Salah satu pemandangan yang dapat di lihat dari desa ini adalah eksotisme keindangan dari telaga Ngebel. Dari desa ini dapat disaksikan dengan jelas hasil karya sang pencipta jagat berupa telaga Ngebel yang menyimpan sejuta keindahan. Dipadupadankan dengan hijaunya pepohohan serta keindahan langit dari atas ketinggian, desa ini benar-benar memiliki potensi yang sangat luar biasa. Bukit dilihat dari antusias para pengunjung yang tidak hanya berasal dari kabupaten Ponorogo, banyak pengunjung yang berasal dari luar kota yang sengaja datang ke Mloko Sewu untuk menyaksikan keindahan Telaga Ngebel dari atas kejauhan.

Seiring dengan banyaknya para wisatawan, peluang banyaknya sampah lokasi wisata juga tidak dapat dipungkiri lagi. Mloko Sewu membutuhkan strategi pengelolaan sampah khususnya sampah anorganik yang sulit untuk diuraikan untuk dijadikan sesuatu yang menunjang destinasi wisata tersebut. Berdasarkan hasil analisis dan observasi langsung kepada masyarakat sekitar yang terlibat dalam pengelolaan wisata tersebut, mereka mengaku terbuka dalam menerima saran maupun masukan untuk permasalahan tersebut guna menuju destinasi wisata yang memiliki identitas wisata

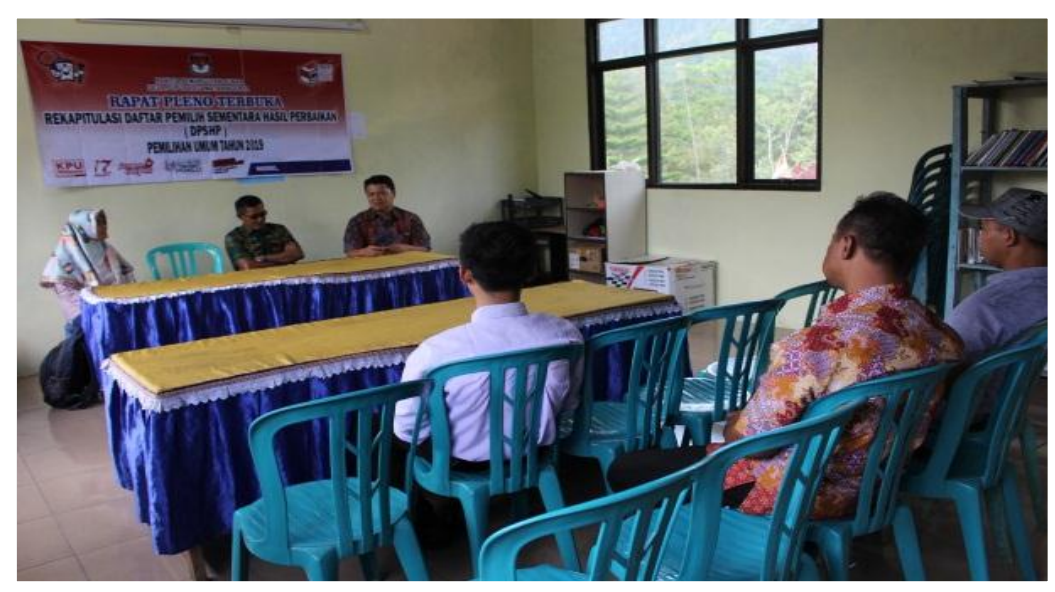

Gambar 3. Sosialisasi dengan perangkat desa

Mloko Sewu biasa masyarakat menyebutnya, sapaan ini berasal dari kata "Mloko" yang merupakan nama Tanaman/Pohon yang banyak tersebar di wilayah tersebut dan "Sewu" (dalam bahasa Jawa) yang berarti seribu. Selain keindahan pada waktu pagi dan siang hari, bukit Mloko Sewu ternyata juga menyimpan rahasia menabjubkan di kala senja datang. Keindahan sunset di waktu sore dapat terlihat jelas di tempat ini. Hal ini yang menjadi daya tarik tersendiri bagi para wisatawan untuk berkunjung di objek wisata ini.

Mloko Sewu kini berkamuflase menjadi destinasi wisata yang dikelola bersama masyarakat setempat melalui peran POKDARWIS (Kelompok Sadar Wisata) daerah setempat. Melalui peran bersama masyarakat Mloko Sewu kini sudah berproses ke arah lebih baik lagi dari yang sebelumnya, hal ini dapat tersendiri disamping destinasi wisata yang lain yang ada di kabupaten Ponorogo.

\section{Konsep Perencanaan}

Program Hibah Bina Desa (PHBD) merupakan program yang diusulkan oleh Badan Eksekutif Mahasiswa (BEM) Universitas PGRI Madiun dan lolos didanai Kementerian Riset, Teknologi dan Pendidikan Tinggi (MENRISTEKDIKTI) tahun 2018. Pengabdian ini berisi suatu konsep gagasan yang bersifat transfer ilmu kepada masyarakat dalam pengelolaan pariwisata dengan memberikan konsep daur ulang (recycle) sampah anorganik berupa botol bekas di lokasi wisata. Salah satu konsep yang diusulkan dalam program pengabdian ini adalah Konsep smart rubbish yang akan diimplementasikan di desa wisata Mloko Sewu, Desa Pupus Kecamatan Ngebel, Kabupaten Ponorogo, Jawa Timur. Konsep ini 
mengusung pemanfaatan kembali limbah anorganik di lokasi wisata berupa botol bekas yang didaur ulang sedemikian rupa hingga tercipta sebuah spot foto (photo corner) di wisata tersebut. Adanya photo corner ini bertujuan untuk memberika edukasi kepada para Implementasi

Konsep smart rubbish telah diimplementasikan melalui peran serta masyarakat sekitar wisata dan dibantu oleh tim PHBD UNIPMA. Realisasi program dilaksanakan melalui beberapa tahap diantaranya adalah sebagai berikut :

1. Sosialisasi

a. Sosialisasi dengan pihak perangkat desa

Sosialisasi kepada pihak kepala desa dilaksanakan pada hari jum'at, 20 Juli 2018 bertempat di kantor kepala desa Pupus kecamatan Ngebel, kabupaten Ponorogo. pengunjung bagaimana limbah anorganik seharusnya dapat dimanfaatkan kembali sekaligus menjadi identitas wisata yang memberikan ciri khas tersendiri disamping konsep wisata yang sudah ada.

masyarakat dapat turut serta membantu mempersiapkan segala keperluannya. Sosialisasi dilaksanakan pada malam hari menyesuaikan waktu luang masyarakat.

2. Pendampingan

Tahap pendampingan dilaksanakan dengan tujuan untuk mendampingi serta mengawasi dalam merealisasikan konsep smart rubbish di wisata Mloko Sewu. Disamping itu pendampingan dilaksanakan melalui bantuan dalam bentuk tenaga oleh tim PHBD UNIPMA untuk mewujudkan konsep smart rubbish supaya benar-benar dapat terealisasi. Pendampingan

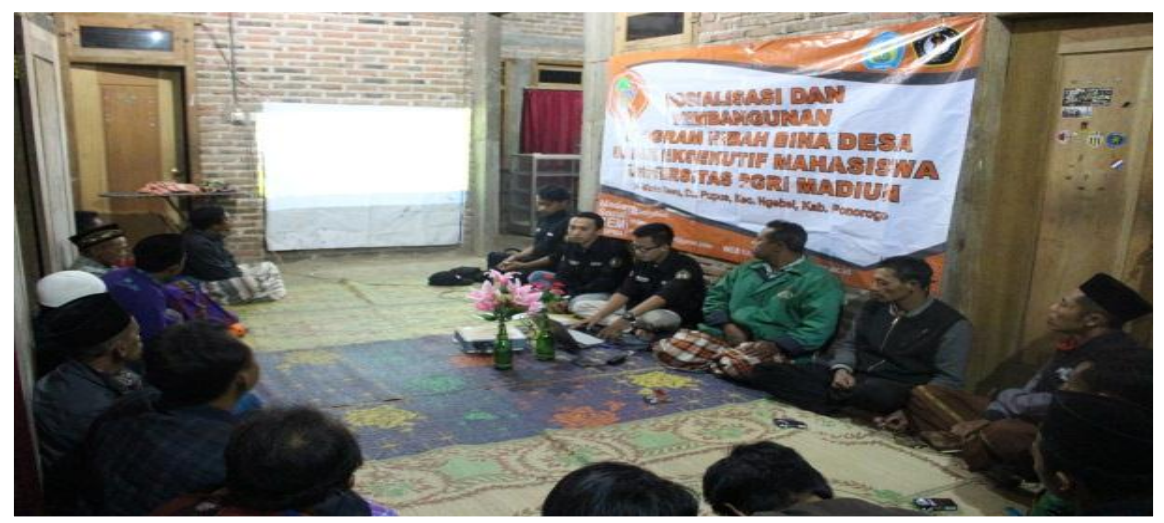

Gambar 4. Sosialisasi dengan pihak masyarakat.

Tujuan dilaksanakan sosialisasi program ini adalah untuk menyampaikan maksud dan tujuan pengabdian yang akan dilaksanakan di desa tersebut sekaligus memohon ijin untuk merealisasikan program tersebut. Hasil dari sosialisasi adalah berupa $\mathrm{MoU}$ sebagai wujud kerjasama antara tim pelaksana dengan pihak desa atas pelaksanaan program tersebut.

b. Sosialisasi kepada masyarakat

Sosialisasi kepada masyarakat dilaksanakan pada hari Jum'at, 3 Agustus 2018, bertempat di salah satu rumah warga dan dihadiri sebanyak 21 orang. Kegiatan Sosialisasi berjalan dengan lancar tanpa suatu kendala. Dalam sosialisasi tersebut disampaikan bagaimana konsep smart rubbish yang akan direalisasikan serta bagaimana tahap implementasinya.

Dalam pertemuan tersebut juga disampaikan keperluan apa saja yang dibutuhkan untuk merealisasikan konsep tersebut sehingga yang dilaksanakan terdiri atas:

a. Persiapan Material

Persiapan material dilaksanakan oleh pihak masyarakat dan dibantu oleh tim PHBD UNIPMA. Masyarakat membantu dalam menyiapkan bahan yaitu bambu petung. Bambu petung banyak tersebar di wilayah tersebut sehingga tidak menimbulkan kendala dalam memperoleh bahan tersebut. Tim PHBD UNIPMA membantu mengumpulkan sampah anorganik berupa botol bekas, baik botol kaca maupun botol plastik. Selain kebutuhan di atas juga dipersiapkan perlatan penjunjang untuk merealisasikan konsep smart rubbish tersebut, seperti: gergaji, cangkul, linggis, parang, tatah, palu paku, kawat, semen, pasir, koral, sekop dan sebagainya. Tidak lupa juga dipersiapkan keperluan untuk mendaur ulang botol bekas berupa cat, vernis, pilok, kuas, tali rafia, bunga sintesis, limbah bunga pinus dan sebagainya. 


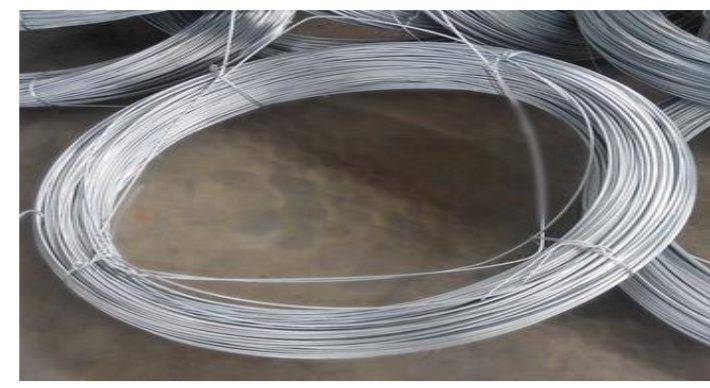

Gambar 5. Kawat Baja

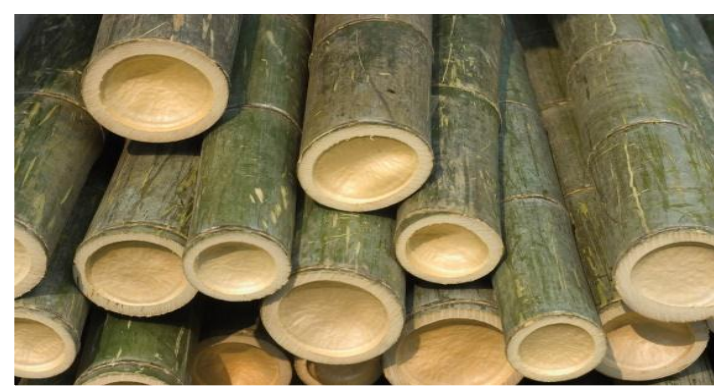

Gambar 7. Bambu Petung

b. Pembangunan

Tahap pembangunan dilaksanakan setelah bahan material telah tersedia semua. Pembagian tugas dibagi menjadi dua, diantaranya Tim PHBD perempuan mempersiapkan daur ulang sampah botol bekas untuk dikreasikan menjadi produk yang memiliki nilai estetika dan tim PHBD laki-laki dibantu dengan pihak masyarakat membuat rak botol bekas yang dibuat dengan menggunakan bambu petung. Pembangunan photo corner dilaksanakan selama dua hari. Tahap pembangunan terdiri atas :

1. Membuat rak botol bekas dari bambu petung

2. Vernis rak botol menggunakan plitur

3. Pengecoran rak botol bekas

4. Pengecatan botol bekas

5. Pemilahan bunga sintetis

6. Finishing akhir photo corner

3. Monitoring dan Evaluasi

Monitoring dilaksanakan dengan tujuan semua kegiatan yang dilaksanakan dapat terkontrol, sehingga setiap kendala yang yang dihadapi selama pelaksanaan program dapat terkondisikan dengan baik. Berdasarkan implementasi yang sudah dilaksanakan sudah barang tentu terdapat beberapa kendala yang dihadapi dalam melaksanakan program tersebut antara lain:

1) SDM dari mahasiswa yang kurang cekatan dalam melaksanakan pekerjaan

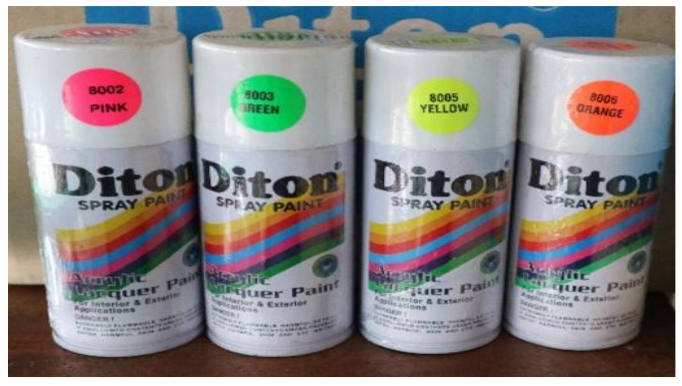

Gambar 6. Pilok

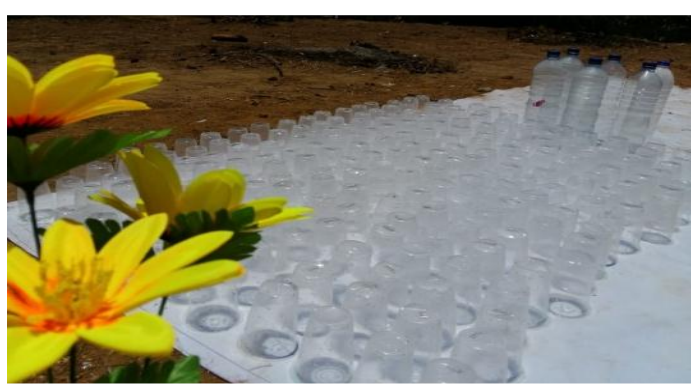

Gambar 8. Limbah Botol Bekas

berat, disebabkan kurangnya pengalaman dan skill yang kurang dalam pekerjaan tukang.

2) Alat yang digunakan dalam membuat photo corner masih sangat tradisional sehingga memerlukan waktu yang sedikit lama.

3) Akses yang jauh dari keramaian kota sehingga menyulitkan ketika membutuhkan keperluan-keperluan yang tidak tersedia di desa tersebut.

4) Selain kendala di atas terdapat juga beberapa masalah dalam merealisasikan program ini, diantaranya adalah:

5) Mloko sewu berada di atas ketinggian dan potensi angin kencang sangat besar, hal ini akan mengganggu kualitas photo corner yang sudah jadi sehingga butuh strategi khusus agar photo corner yang sudah jadi tidak terbawa angin. Solusi : mengecor rak bambu menggunakan semen agar dapat berdiri kokoh dan tidak mudah rubuh.

6) Kontur tanah pada Mloko Sewu sangat gembur dan berdebu khusunya di musim kemarau. Banyaknya debu yang terbawa angin menyebabkan photo corner cepat kotor. Hal ini akan berdampak pada ketahanan photo corner yang tidak akan bertahan lama jika tidak ada penanganan khusus. Solusi : melakukan pengecekan terhadap photo corner dan membersihkan botol yang kotor. 
7) Akses air yang terbatas ditambah kontur tanah yang gembur mengakibatkan tanaman tidak mendapatkan air dengan maksimal, hal ini menyebabkan tanaman mudah layu karena kekurangan air. Solusi : menggunakan selang untuk akses penyiraman tanaman.

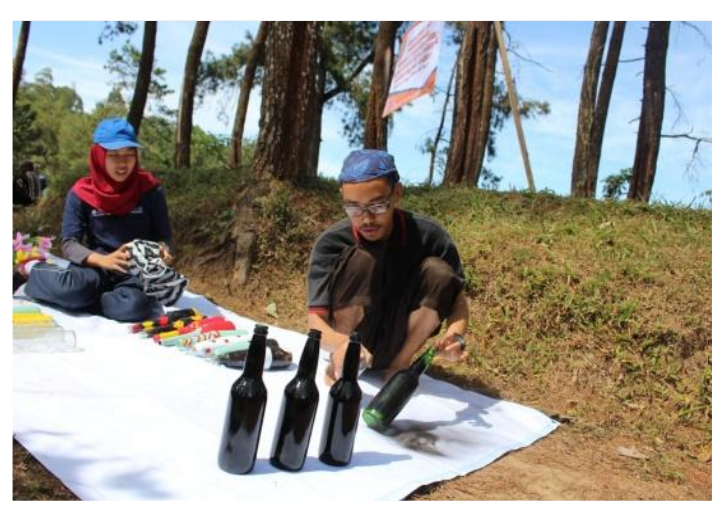

Gambar 9. Proses pewarnaan botol kaca bekas

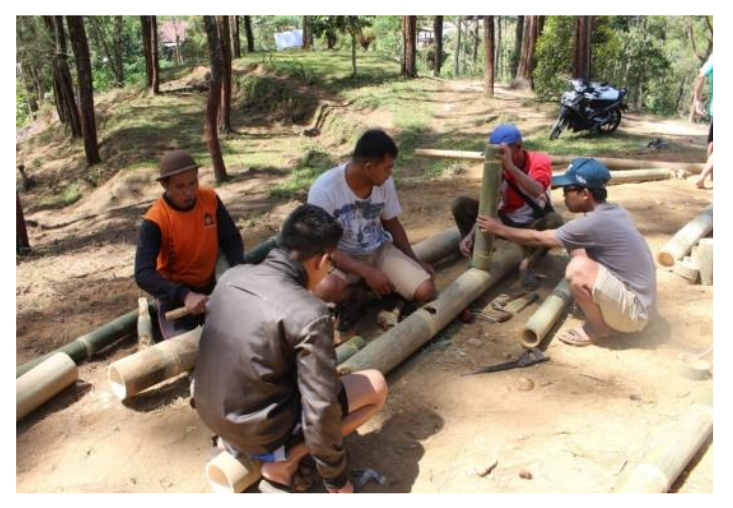

Gambar 11. Proses pembuatan rak bunga

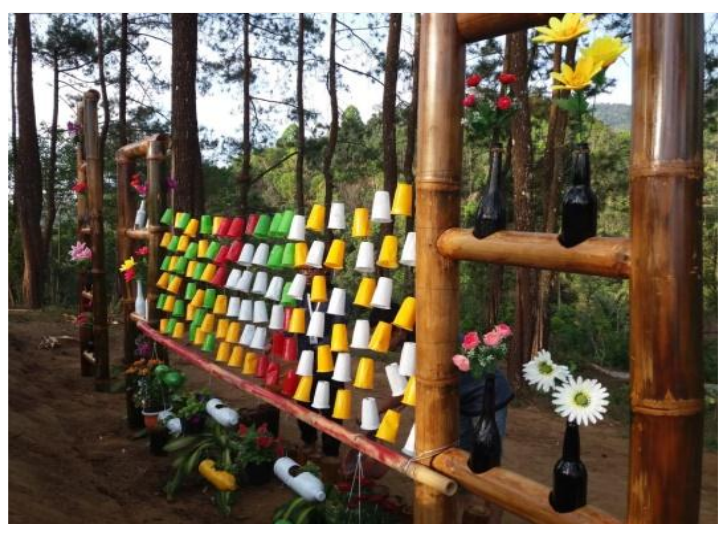

Gambar 13. Hasil akhir photo corner dengan konsep smart rubbish

\section{SIMPULAN}

Konsep smart rubbish merupakan salah satu alternatif yang dapat digunakan untuk menangani permasalahan akan sampah di lokasi wisata, khususnya sampah botol. Konsep ini

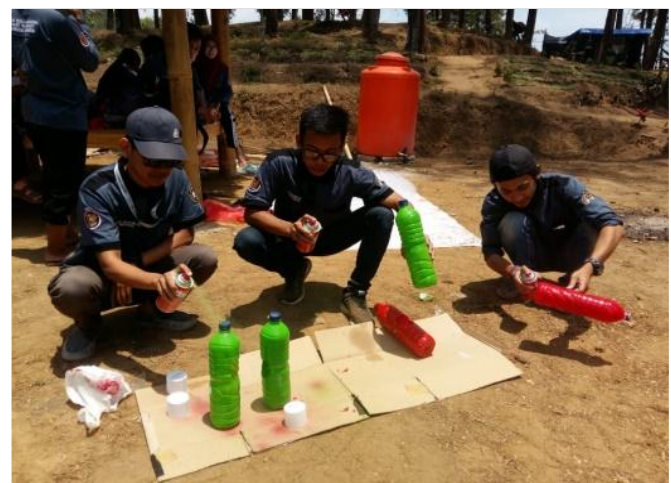

Gambar 10. Proses pewarnaan botol bekas

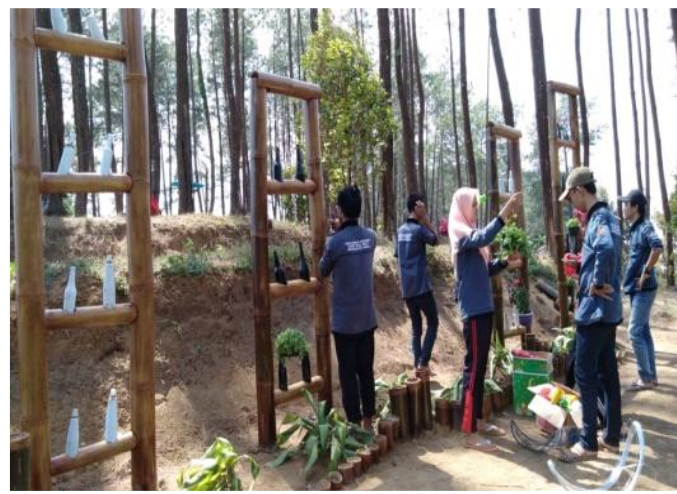

Gambar 12. Pemasangan botol pada rak

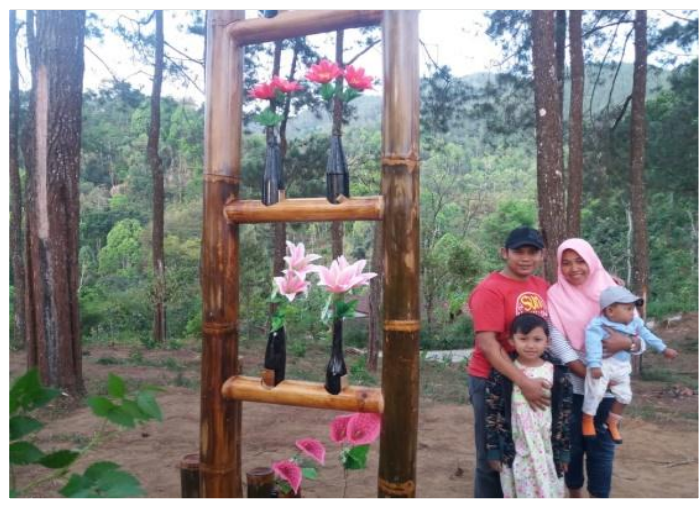

Gambar 14. Pengunjung Mloko Sewu

mengusung salah satu prinsip yang diterapkan dalam pemanfaatan sampah anorganik (4R) yaitu recycle (mendaur ulang). Sampah botol akan didaur ulang menjadi sebuah spot foto (photo corner) yang akan menunjang destinasi wisata 
tersebut melalui sebuah konsep pendaulangan sampah yang memiliki nilai estetika. Konsep smart rubbish diimplementasikan pada wisata Mloko Sewu, desa Pupus, kecamatan Ngebel, Kabupaten Ponorogo. Penerapan konsep smart rubbish ini bertujuan untuk memberikan nilai edukasi kepada para wisatawan bagaimana sampah anorganik selayaknya harus ditangani dengan cara-cara cerdas dan kreatif. Selain itu dengan adanya konsep smart rubbish ini diharapkan mampu menjawab permasalahan banyaknya sampah anorganik di lokasi wisata sekaligus mampu menjadi salah satu indentitas wisata dengan konsep daur ulang sampah disamping banyaknya konsep wisata lain yang sudah ada di bumi reog Ponorogo.

\section{DAFTAR PUSTAKA}

Hijriati, E., \& Mardiana, R. (2015). Pengaruh Ekowisata Berbasis Masyarakat Terhadap Perubahan Kondisi Ekologi, Sosial Dan Ekonomi Di Kampung Batusuhunan, Sukabumi. Sodality: Jurnal Sosiologi Pedesaan, 2(3).

PS, T. P. (2008). Penanganan dan pengolahan sampah. Jakarta: Penebar Swadaya.

RI. Undang Undang Republik Indonesia Nomor 18 Tahun 2008 Tentang Pengelolaan Sampah (2008). Indonesia.

RI. Undang Undang Republik Indonesia Nomor 10 Tahun 2009 tentang Kepariwisataan (2009). Indonesia.

Sekaran, U., \& Bougie, R. (2017). Metode Penelitian Untuk Bisnis: Pendekatan Pengembangan-Keahlian Buku 1 (6th ed.). Jakarta: Salemba Empat 